\title{
LEIS ORIGINARIAMENTE INCONSTITUCIONAIS COMPATÍVEIS COM EMENDA CONSTITUCIONAL SUPERVENIENTE
}

\author{
CElso ANTONio BANDEIRA DE MELlo*
}

1. A questão que nos propomos a abordar refere-se ao seguinte interessante tema de alta indagação teórica: Disposição legal que viola materialmente as normas de uma Constituição será ou não "recepcionada", "convalidada" ou meramente validada por Emenda Constitucional, caso seu regramento seja compatível com as disposições novas estabelecidas pela Emenda?

De passagem, anote-se que não se está a pôr em pauta o tópico, muito amplamente versado na doutrina, relativo à compatibilidade de norma originariamente inconstitucional com nova Constituição. O que se quer examinar é o mesmo problema em face de Emenda Constitucional, assunto, este, bem menos discutido que o anterior.

2. Registre-se, de saída, que ambas são questões visceralmente distintas, pois nova Constituição significa ruptura com a Constituição precedente, já que a nova não encontra seu fundamento de validade na anterior, não se reporta, de direito, a ela, prescinde radicalmente daquela que a precedeu a submerge por inteiro.

Diversamente, uma Emenda Constitucional, modifica, mas não rompe com a Constituição anterior, não perime a Lei Magna antecedente. Precisamente o inverso: continua com a anterior Constituição, encontra nela seu fundamento de validade, a ela se reporta e nela se integra, não afetando a persistência da ordem jurídica de que faz parte. Dessarte, reponta um laço incindível entre a Emenda e a Constituição emendada, do que resulta uma solidariedade jurídica entre os termos antigos e os novos de um só e mesmo Documento Fundamental.

Tratando-se, pois, como visto, de questões distintas, para o desenvolvimento do assunto que nos propomos a versar, é desnecessário determo-nos sobre aquele que não está sob o presente foco de atenção. Isto, contudo, não nos pode liberar de tecer algumas considerações genéricas relativas a sobrevinda de Constituições novas e seus efeitos, para fins de realçar a diferença que apresentam no que concerne a Emendas.

* Titular da Faculdade de Direito da Universidade Católica de São Paulo.

R. Dir. Adm.,

Rio de Janeiro, 215: 85-98, jan./mar. 1999 
3. Uma vez que uma Constituição é a inauguração de um sistema sem conexões jurídicas com aquele que o antecedeu, perempto o sistema anterior, tudo que a este pertencia, que nele se estribava e dele derivava, em princípio, teria que desaparecer. Donde, todas as normas infraconstitucionais precedentes. em tese. deveriam desaparecer. porque sua relação de pertinência, sua referibilidade - em uma palavra: o suporte que thes infundia e proporcionava existência jurídica - deixou de existir com a sobrevinda de nova Constituição.

Sem embargo. sabe-se que. mesmo perante a sobrevinda de uma nova Constituição, as normas infraconstitucionais preexistentes nem por isto perimem. E considera-se que não perimem mesmo quando a Constituição posterior se omite em ressal vá-las, isto é, mesmo quando deixa de oferecer-lhes explicitamente seu suporte de validade, declarando-as acolhidas.

A razão deste entendimento é puramente prática. É o imperativo de mantê-las vivas para superar a dificuldade gigantesca de ter que começar a legislar da estaca zero. Daí a interpretação corrente, absolutamente generalizada, segundo a qual a Constituição nova, implicitamente, "recepciona" regras anteriores a ela e com ela compatíveis, as quais passam a se fundamentar no sistema novo, sendo certo que as incompatíveis perimem "ipso jure". Registre-se, de passo, que não se está aqui a cogitar da questão paralela de saber-se qual o destino das leis que nasceram defeituosamente em face da Constituição anterior, isto é, que padeciam de invalidade (ou seja, eram inconstitucionais), mas que são compatíveis com a nova Constituição (pois este não é o objeto ora "sub examine").

Do que foi dito já se verifica que a persistência de normas infraconstitucionais anteriores a nova Constituição não é uma implicação lógica, ou seja, não é derivada da aplicação de um raciocínio abstrato que reclamasse tal conclusão. Pelo contrário, o raciocínio abstrato conduziria a conclusão oposta. É a necessidade concreta - e o Direito é concebido em função de necessidades práticas e operativas - que leva ao expediente de haver como "recepcionadas" normas preexistentes.

4. Já na hipótese de Emenda Constitucional, o fenômeno é outro, pois o sistema não está rompido, a Constituição continua em vigor e portanto persiste sendo a fonte de validade de quaisquer normas. Assim, em face de Emendas não há sequer por que propor o tema da continuidade das normas anteriores, isto é, o tema da "recep̧̧ão" visto que não comparecem as razões que infirmariam as leis precedentes. Em suma: elas não teriam por que ser "recepcionadas", pois no sistema estavam e nele continuam.

Frisa-se tal ponto para exibir que a questão que nos propomos a defrontar concerne a um tópico desligado do tema da pertinência de uma norma a um dado sistema e sua "recepção" em outro. O que entra em pauta não é, pois, a questão da prorrogação da "existência" de uma norma (por via de "recepção"), mas exclusivamente o tema da validade dela, já que, embora incompatível com diç̧ões constitucionais precedentes, apresenta-se, entretanto, como compatível com as diç̧ões novas introduzidas pela Emenda.

Assim, o assunto cogitável é outro, completamente distinto daquele até o presente referido. É o de saber-se se, em tal caso, as disposições da Emenda trazem consigo (ou não) o efeito de vir a ofertar um "suporte de validade" "a posteriori", 
para leis originariamente inconstitucionais, vale dizer, para leis que surgiram em descompasso com o texto anterior. o alterado.

$O$ fenômeno como se vê, também não é (ou ao menos não necessariamente o seria) o da "convalidação", pois esta tem sempre efeitos retroativos.

5. Dessarte, enquanto não completada a discussão sobre a superveniência de fundamento de validade para regra que dela presumidamente dantes carecia e firmada uma conclusão sobre seus efeitos, mantém-se irresoluto um problema que, em tese, comportaria as seguintes quatro alternativas de resposta:

a) uma regra que não foi, no passado, oficialmente reconhecida - e pelos meios próprios - como inconstitucional, é existente e válida desde o início, pois sua invalidade dependeria de haver sido constituida no pretérito; logo, se antes os termos da Emenda nada se lhe pode censurar, seria um sem-sentido pretender recusar-lhe, no presente, uma validade que nunca deixou de ter;

b) a regra acoimada de originariamente inconstitucional, ainda que eferivamente o fosse, se compatível com a Emenda, fica retroativamente validada, porque passou a estar de acordo com a Constituição e não se pode considerar inconstitucional aquilo que, no presente, se encontra afinado com ela;

c) a regra originariamente inconstitucional, se compatível com a Emenda, dela receberá um fundamento de validade "a posteriori", entretanto, só oferecerá esteio para seus efeitos a partir da própria Emenda, seja pelo simples princípio da irretroatividade, seja porque, a ser de outro modo, franquear-se-ia a burla ao próprio sistema, efetuável mediante produção de leis inconstitucionais em antecipação a Emendas futuras ou, dito pelo inverso, bloquear-se-ia o reconhecimento de inconstitucionalidades graças ao expediente de produzir emenda sucessiva, o que representaria uma fragilização do sistema;

d) a regra originariamente inconstitucional continua a padecer de inconstitucionalidade, pois a lisura de um ato - pertencente a um mesmo sistema constitucional - pelo necessário respeito à sua integridade absoluta deve ser sempre apreciada ao lume das normas do tempo em que foram produzidas. Se assim não fosse, tal como observado no item anterior, estar-se-ia reconhecendo que o sistema assume, admite e conforta, de antemão, a validação de burlas a si próprio, o que seria ilógico e inadmissível; donde, reconhecer validação "a posteriori” - mesmo que não retroativa - seria contemporizar com tal desrespeito.

6. A primeira das alternativas é a que demanda, para sua análise, maiores detenças, pois sua sustentação depende de conceitos objeto de funda controvérsia doutrinária. Envolve a definição de posições sobre os temas da "existência" e da "validade" de uma norma e traz consigo a concepção de que ambas se reduzem a uma coisa só, motivo pelo qual à invalidação se atribui natureza "constitutiva" e não declaratória.

Ou seja: entende que, enquanto uma norma não for expulsa do sistema pelos meios previstos, ela é, só por isto, válida. Logo, descaberia considerar inconstitucional determinada regra que esteja dentro do sistema. ficando, pois, liminarmente excluída a hipótese de pretender negar-lhe a admissibilidade.

Verifica-se, então, que seu exame obriga a tecer considerações quer sobre o tema da "existência" (ou "pertinência" de uma norma a dado sistema), quer sobre 
o da "validade". Implica tomar posição quanto a serem ou não coisas distintas, sendo este o ponto de partida para sopesar a procedência ou improcedência desta alternativa exegética ante o problema das possíveis consequiências de compatibilidade de uma dada norma com Emenda Constitucional superveniente.

7. O entendimento segundo o qual um ato é "válido" enquanto não for expelido do sistema, pois validade e existência são uma coisa só, atrela-se ao pensamento de KELSEN, segundo o qual:

"Com a palavra "validade (Geltung)" designamos o modo de existência específico das normas'.

ou ainda:

"Esta validade de uma norma é a sua específica existência ideal. O fato de que uma norma "seja válida" significa que existe. Uma norma que não "seja válida" não é uma norma, por não ser uma norma que existe"?.

Daí sua conclusão de que falar-se em lei inconstitucional - antes que órgão autorizado para expelir a lei assim o decida - é um sem-sentido, pois a declaração de inconstitucionalidade é sempre constitutiva.

Esta intelecção, que no passado pareceu-nos verdadeira, ainda que jamais a houvéssemos sufragado por escrito, conquanto a tenhamos expendido verbalmente muitas vezes - e que, em rigor, se encontrava em aberta contradição com outros tópicos de nosso pensamento expressado em diversas obras ${ }^{3}$ (não há senão confessá-lo) - é incorreta e inaceitável.

Com efeito, para que se possa predicar validade ou invalidade de uma norma encartada em dado direito positivo, cumpre antes, lógica e juridicamente, que tal norma exista naquele sistema.

8. Os dois tópicos não podem ser confundidos porque o tema da existência de um ato, de uma norma. diz com sua referibilidade a um dado sistema normativo, concerne a sua "pertinência" ao sistema no qual se encarta ou se propõe a encartar-se. Uma lei pertence ao direito positivo brasileiro (ou inglês, ou francês ou espanhol), porque "promana" daquele sistema jurídico. Ou seja: é lei brasileira (e não inglesa, francesa ou espanhola) porque se "radica" no sistema jurídico positivo brasileiro.

Este "promanar", este "radicar-se", significa que a lei foi produzida com fundamento naquele sistema, o que equivale a dizer, com fundamento (bom ou mau, procedentemente sustentável ou não) na Constituição do País, por ser ela que unifica

1 Hans Kelsen, Théorie Pure du Droit, trad. francesa da $2^{2}$ ed. da "Reine Rechtslehre", por Charles Einsenmann, Dalloz, Paris, 1962. p. 13.

2 Hans Kelsen - Teoria Generale delle Norme - trad. italiana da edição póstuma do "Allgemeine Theorie der Normen", por Mirella Torre sob os cuidados de Mario Losano, Giulio Eunaudi Ed., Torino, 1985 , p. 54.

3 Assim, de há muito distinguimos explicitamente existência de validade. Cf. notadamente, Curso de Direito Administrativo, cit., $4^{\mathrm{a}}$ ed., 1993, p. 177: "Sem os elementos não há ato jurídico algum (administrativo ou não). Sem os pressupostos não há ato administrativo formado de maneira válida". Mais tarde. em edições posteriores procuramos aperfeiçoar o tratamento do tema dos elementos e pressupostos do ato, distinguindo a partir da $8^{\mathfrak{a}}$ ed.. 1996, os pressupostos de existência do ato de seus pressupostos de validade. às pp. 220 e ss. 
e dá identidade ao sistema. Ela é que serve de escoro, fonte de pertinência da norma ao sistema em questão. E sua referibilidade original àquele sistema o que faz uma lei (e assim também qualquer outro ato), ser ou não uma lei brasileira (ou inglesa, francesa ou espanhola).

É certo que enquanto não for expelida do sistema pelos meios previstos como idôneos para tanto, a norma nele permanecerá e produzirá seus efeitos, o que, todavia, não significa que possua atributos de validade. Pode ter nascida em descompasso com norma superior, contradizendo formal ou materialmente preceitos que teria de respeitar. Estará vigorante, será eficaz - se não pender de algum termo inicial mas nem por isto ter-se-á de concluir que é válida.

Em suma: a existência de uma norma, sua pertinência a um sistema jurídico, nada predica quanto à sua validade ou invalidade.

9. Tratando do ato administrativo - mas o conceito expendido vale para qualquer ato jurídico, geral e abstrato, como as leis soem ser ou concreto e específico como em sua maioria o são os administrativos - depois de separar a "existência" do ato, isto é sua "perfeição" da validade, expendemos nosso entendimento ao respeito da validade. nos seguintes termos:

" $O$ ato administrativo é válido quando foi expedido em absoluta conformidade com as exigências do sistema normativo. Vale dizer, quando se encontra adequado aos requisitos estabelecidos pela ordem jurídica. Validade, por isto, é a adequação do ato às exigências normativas. "4

Invalidade, pois, é a antítese da validade. Ato inválido é o que foi expedido em descompasso com as exigências do sistema normativo. É o que contraria os requisitos por ele estabelecidos. É o inadequado às exigências a que teria de se submeter, quer formal, quer materialmente. Quando o ato é inválido, em face da lei, diz-se que é ilegal; quando inválido. em face da Constituição, diz-se que é inconstitucional.

Assim, lei produzida em desacordo com os ditames da Constituição, é norma inconstitucional ou seja, norma que nela não encontra bom fundamento para suster-se.

10. Em todos os sistemas jurídicos existem normas que regulam a admissão e normas que regulam a expulsão de normas. Uma norma referida a dado sistema, isto é, que haja sido por ele produzida, que com ele guarde a "relação genética de pertinência", é uma norma existente e nele permanecerá enquanto não for expulsa pelas formas de expulsão ali contempladas. A invalidação, ora chamada de anulação ora de nulidade, tanto como a revogação, são formas previstas de expulsão. A invalidação - e assim, pois, $a$ invalidação por inconstitucionalidade - é, portanto, uma forma de expelir norma descompassada com a Constituição.

Verifica-se, então, que validade é coisa diversa de existência ou pertinência atual de uma norma a um certo sistema. Com efeito, um ato inválido, só por sê-lo, não é um ato inexistente. Portanto, uma lei inconstitucional, só por sê-lo, não é uma lei inexistente. Enquanto não for expulsa do sistema, nele persistirá. De outro lado, um ato existente, só por sê-lo. não é um ato válido. Do mesmo modo. uma lei que 
viola a Constituição, não será válida, não será constitucional, pelo só fato de existir. isto é, pelo fato de não haver sido expulsa do sistema.

11. O ato de invalidar (o ato de declarar diretamente ou de reconhecer, "incidenter tantum", a inconstitucionalidade de uma lei) pressupõe, de logo, que se esteja perante uma norma integrante do sistema e pressupõe, outrossim, não apenas logicamente (como dantes, aliás, equivocadamente supunhamos), mas também juridicamente, que o ato dessarte atacado seja inválido.

Ou seja. tal exigência é inafastável do ponto de vista lógico - já que invalidar depende de um juízo recognitivo da invalidade, logo, de um "status" lógico que preexistia à invalidação - e é igualmente inafastável do ponto de vista jurídico porque o órgão que procederá à invalidação não teria outro titulo jurídico para fazế-lo senão o de que se trata de um ato inválido.

Quer-se dizer: o juiz - tomemo-lo como paradigma - não está, de direito, qualificado para invalidar senão quando o ato careça de validade. Nada importa que tal juízo tenha de ser feito por ele mesmo, pois, de qualquer modo, sua pronúncia neste sentido está, pelo próprio Direito, previamente atrelada à condição jurídica da invalidade do ato (lei ou qualquer outro). Deveras, a questão relativa a quem procede ao ato de reconhecimento da invalidade é questão distinta da exigência jurídica de prévia invalidade, para que possa ser pronunciada.

12. Ao nosso ver, a demonstração mais cabal e irretorquível de que existência, pertinência de uma norma a dado sistema, e validade são noções absolutamente inconfundíveis tem-se no fato de que, no exame da inconstitucionalidade "incidenter tantum", o juiz não aplica uma norma jurídica por considerá-la inconstitucional, ou seja "carente de validade", "inválida", mas nem por isto a expulsa do sistema (falece-lhe atribuição para fazê-lo), o que só ocorre na ação direta de inconstitucionalidade.

A norma em questão continuará a existir dentro do sistema, mas sua validade terá sido questionada como algo autônomo em relação a existência e proclamada como suficiente para impedir sua aplicação ao caso concreto.

Vale dizer: o juiz assume que a invalidade de uma norma é coisa diversa de sua existência ou pertinência ao sistema. Para, "incidenter tantum" desaplicar uma regra que houve por inconstitucional, o pronunciamento judicial restringe-se ao tema da validade da lei perante a Constituição. É o quanto bastaria para ter-se que rejeitar a tese Kelseniana de que "validade é a forma específica de existência de uma norma jurídica". Não é. Deveras, como visto, nega-se validade a ela, por ser este o único fundamento para desaplicá-la no caso concreto, mas não se nega, nem se interfere com sua existência.

13. Quem explica com percuciência e clareza o equívoco de KELSEN é o ilustre jurista pernambucano MARCELO NEVES. Vale, portanto, transcrever, trechos de suas lições a este propósito:

"A teoria para do Direito, definindo a validade como a existência específica de uma norma jurídica, confundiu os conceitos de pertinência e validade, enquanto conformidade à "norma fundamental" do sistema jurídico. Também Hart, considerando o Direito do ponto de vista interno, confundiu expressamente estes dois conceitos, no sentido de que só pertenceriam ao sistema (seriam válidas) as normas 
("regras") que satisfizessem a todos os requisitos estabelecidos na regra de reconhecimento.

Contudo, o ordenamento jurídico, por constituir espécie de sistema normativo dinâmico, tolera a incorporafão de normas jurídicas, que permanecerão no sistema enquanto não houver produção de ato jurídico ou norma jurídica destinada a expulsá-las, isto é, até que se manifeste o órgão competente desconstituindo-as. Portanto, ao passo que nos sistemas normativos estáticos, onde as normas são explicitadas mediante processos de derivação lógico-dedutiva desenvolvidos a partir de uma norma básica, a pertinência da norma implica sua validade e vice-versa, os sistemas juridicos construidos e desenvolvidos através dos processos políticos e técnicos de produção-aplicação normativa, caracterizam-se por uma nítida distinção entre pertinência e validade das normas.

Aqui, há analogia com a distinção de Pontes de Miranda entre existência e validade dos atos jurídicos, também aplicadas às normas jurídicas. A "existência" de um ato ou norma jurídica, segundo Pontes de Miranda, constitui-se por sua entrada no "mundo juridico". Quando o ato jurídico entra defeituosamente no "mundo jurídico", há "existência" sem validade. Portanto, distinguem-se os planos da existência e da validade. Os atos e normas jurídicas são válidos quando produzidos regularmente pelos agentes do sistema (órgãos em sentido estrito ou particulares). A invalidade resulta da integraçāo ao "mundo juridico" de atos e normas produzidos defeituosamente pelos agentes do sistema".5 (os destaques são nossos).

E poucas páginas além:

"O fato de pertencerem ao sistema juridico normas inválidas confirma o que sustentamos anteriormente: no ordenamento jurídico, ao contrário do que ocorre nos sistemas nomológicos e nos sistemas normativos estáticos, a hierarquia das proposições não e absoluta, perfeita (.. ) A explicaçāo semiótica desta situação pertinência ao ordenamento jurídico de normas inválidas - encontra-se nas caracteristicas semânticas e pragmáticas do discurso juridico. A plurivocidade significativa da linguagem jurídica (problema semântico), utilizada pelos diversos órgãos que exercem o poder e também pelos destinatários do poder (problema pragmático). implica a exigência prática de que a norma permaneça no sistema enquanto nāo seja desconstituida por órgāo competente, caracterizando-se a presunção juris tantum de validade das normas emanadas de órgãos do sistema ..."6.

Cabe, aqui apenas, a seguinte anotação: a norma permanecerá no sistema enquanto não desconstituida sua existência, isto é, sua pertinência ao sistema - o que é absolutamente verdadeiro - mas poderá, sobre o fundamento de que é inválida, ser desaplicada pelo juiz no exame de constitucionalidade "incidenter tantum", como já se disse, nisto se confirmando e comprovando inadversavelmente a distinção jurídica entre existência e validade.

14. Verificada, então, a improcedência dos fundamentos teóricos que alicerçariam a primeira alternativa exegética dantes mencionada, demonstrada está a impro-

5 Marcelo Neves, Teoria da Inconstitucionalidade das Leis, Ed. Saraiva, 1988, pp. 40-41.

6 Idem, pp. 45-46. 
cedência da tese segundo a qual uma regra que não foi, no passado, oficialmente reconhecida - e pelos meios próprios - como inconstitucional é existente e válida desde o início.

15. Isto posto, passemos ao exame da segunda alternativa. segundo a qual lei originariamente inconstitucional, pelo simples fato da superveniência de Emenda Constitucional com a qual seja compatível, adquire suporte de validade retroativo, pois inconstitucionalidade se examina ante as normas presentes.

Esta posição, ao contrário da anterior, carece de estribo em bases teóricas elaboradas.

Com efeito, nada justificaria a retroatividade do suporte de validade sobrevindo. tanto mais porque, em nosso sistema, vigora explicitamente o princípio da irretroatividade das leis, cujo fundamento lógico e jurídico (o da segurança jurídica) tanto comparece no caso de leis quanto, por identidade de razão, no caso de Emendas Constitucionais, porque nenhum motivo haveria para que em face delas deixasse de vigorar.

Deveras, se se estivesse perante hipótese de Constituição nova, poder-se-ia entender que, pela falta de relação entre ela e a precedente, a posterior não teria razão para zelar pela lisura das regras infra constitucionais que a precederam, assim como não teria (ou pelo menos não o teria obrigatoriamente) que evitar a retroação de seus dispositivos, conquanto seja certo que, mesmo em tais casos, em favor da segurança jurídica, as Constituições - salvo no que elas mesmas hajam disposto em contrário - sempre têm sido entendidas como não retroativas, até porque, a ser de outro modo, instaurar-se-ia o caos social ${ }^{7}$.

Assim, a regra, ineludivelmente, é a da não-retroação, motivo por que os termos de Emenda não têm por que retroagir para conferir validade inicial a uma lei que originalmente dela carecia.

16. Quando se está perante Emenda, está-se consoante já foi reiteradamente dito - sempre perante a mesma Constituição. Donde. já não se poderá dizer que a ela é indiferente ou irrelevante, a lisura da obediência aos seus termos anteriores, dadas as repercussões futuras disto, como ao diante se demonstra. Muito menos poder-se-á dizer que lhe é irrelevante o tema da retroação, pela instabilização que provocaria naquele mesmo sistema que persiste em vigor, pois as normas da Emenda são intrasistemáticas, e as infraconstitucionais obviamente também o são, quer sejam anteriores, quer sejam posteriores à Emenda. Segue-se que sua lisura, sua validade original, não é estranha àquela mesma Constituição, conquanto emendada. Logo, o exame de sua validade há de ser feito normalmente, isto é, confrontando-a com as normas superiores vigentes ao tempo em que foi editada.

7 Registre-se que a referência feita é à "irretroatividade" e não ao "direito adquirido", o qual propõe problema diverso: o da ultra-atividade da norma antiga. Pela teoria do direito adquirido, o que se protege são certos direitos nascidos no passado que transitam no presente e se projetam para o futuro, pretendendo-se involucrá-los com o manto protetor da norma antiga; ou seja, quer-se que continuem regidos pelos termos dela. 
De outra parte, se, como assinalado, o princípio, a regra, é a irretroação, mesmo no caso de Constituição nova, maiormente o será no caso de simples Emenda, motivo pelo qual, a admitir-se que sua superveniência ofereceria suporte de validade para lei originariamente inconstitucional, por certo tal suporte não poderia senão conferir-lhe efeitos a partir da Emenda. (Tal como admitido naquela que seria, consoante indicado, uma terceira alternativa exegética).

17. Assim, por estas razões, de fora parte as que serão apresentadas em seguida, deve ser rejeitada radicalmente a interpretação segundo a qual, com a sobrevinda de Emenda Constitucional, adquire retroativa validade a lei anterior que com ela se compadece, mas que brigava com o texto precedente.

18. Conforme a terceira alternativa exegética, o entendimento correto é a outorga de validade à lei originariamente inconstitucional consonante com a Emenda sucessiva, porém tais efeitos só se poderiam contar dali por diante. Ou seja: não se lhes poderia reconhecer validade desde o passado, tanto porque isto implicaria atribuir força retroativa à Emenda, quanto porque, se isto fosse tolerável, franquear-se-ia a burla ao próprio sistema, efetuável mediante produção de leis inconstitucionais em antecipação a Emendas futuras ou, dito pelo inverso, bloquear-se-ia o reconhecimento de inconstitucionalidades, graças ao expediente de produzir emenda sucessiva, o que representaria uma fragilização do sistema.

Trata-se de argumento fortíssimo e que demonstra a repercussão negativa (não apenas no presente, mas também para o futuro do próprio sistema) implicada na tese da validação retroativa de norma inconstitucional.

De fato, é impossível acolher-se um critério exegético por força do qual irroga-se ao ordenamento jurídico a assunção da idéia de que compactua com burlas que the hajam sido feitas e de que compactuará com as que lhe venham a ser feitas e que validará comportamentos produzidos em desacordo com seus ditames. Ou seja, isto corresponderia a atribuir ao ordenamento a proclamação de que, desde que sejam praticadas tais burlas, outorgar-lhes-á seu aval (e, ademais, irrestrito, segundo aqueles que lhe atribuem validação retroativa).

19. Em relação a um contra-senso desta ordem, assim se pronunciaram dois exímios constitucionalistas de máxima suposição, CANOTILHO e VITAL MOREIRA:

"Pode suceder, como se viu, que uma norma vigente tenha sido inconstitucional no passado, tendo deixado de o ser a partir de certo momento, por efeito da revisão constitucional (ver infra cap. VII, 4.2.)

Esta inconstitucionalidade pretérita nāo perde relevância em relação ao período em que se verificou, sendo-lhe aplicáveis os mecanismos do sistema de fiscalização da constitucionalidade, incluindo a declaração de inconstitucionalidade com força obrigatória geral com referência ao período em causa.

Diferente é o caso das normas que tenham sido inconstitucionais à face de normas constitucionais anteriores à CRP (abreviatura, esclareça-se, de Constituição da República Portuguesa) e tenham deixado de o ser à face desta. Por princípio, o sistema de fiscalização da constitucionalidade não pode servir para fiscalizar senão 
o cumprimento da constituição vigente, "ainda que em versão anterior""8 (este destaque é nosso).

Mais além, no capitulo VII, item 4.2., referido na citação acima, os autores fazem o seguinte importantíssimo comentário:

"Também no que respeita ao direito ordinário anterior inconstitucional à face da Constituição antes da revisão, não deverá considerar-se como retroactivamente convalidado, só por deixar de ser contrário à Constituição após a revisão. Desde logo, por uma razão prática: a admitir-se essa solução, estaria aberta a porta para 'revisões' antecipadas por via de lei ordinária, feitas 'à conta' de futura revisão constitucional; por outro lado, a razão invocada para convalidar o direito ordinário anterior Constituição - designadamente a de que os órgãos de fiscalização da constitucionalidade não podem ser guardiões de uma ordem constitucional perimida - não colhe aqui, pois a ordem constitucional continua a ser a mesma, embora parcialmente alterada. Portanto, a 'convalidação' não poderá retroagir ao tempo anterior ao da lei de revisão e só tem sentido em relação à inconstitucionalidade material, não em relação à inconstitucionalidade formal ou orgânica, pois estes tipos dizem respeito à formação do acto normativo, não podendo ser sanados a posteriori" 9 .

20. Agregue-se a isto, desde logo, a observação de que a razão impediente do efeito retroativo, não é apenas prática, como apontaram os autores. É também teórica, conforme dantes procuramos demonstrar. Acolhê-la implicaria - repise-se - atribuir ao ordenamento a contradição essencial de justificar, e por antecipação. burlas a si próprio, isto é, fraudes à Constituição, dando-lhe previamente seu apoio.

Por isto mesmo, dita razão, em seu aspecto prático, mas muito mais em seu aspecto teórico, inibe não apenas a retroação mas também a própria validação da norma originariamente inconstitucional que seja consonante com o teor da Emenda superveniente.

21. Eis por que, não é de acolher esta que indicamos como terceira alternativa exegética. Incorre no ilogismo (ademais de incorrer na inconveniência) de pressupor que o ordenamento constitucional compactua com sua própria violação, postergando a evidência de que o primeiro objetivo, a própria razão de existir de um ordenamento jurídico, é ser respeitado. Não o de ser fraudado e, ademais com a garantia prévia de que avalisará a burla que lhe seja feita. Dessarte, não pode ser aceito o entendimento de que Emenda Constitucional confere validade, mesmo que não retroativamente, a inconstitucionalidades originárias.

22. Deveras, se ante os termos de uma dada Constituição, certa norma não pode ser produzida, porque confrontaria com a Lei Magna, é direito, é garantia, dos administrados serem liberados dos gravames que tal norma lhes causaria, mediante exibição, na esfera própria, de sua inconstitucionalidade. Mas, se for reconhecido ao próprio autor da inconstitucionalidade, ao próprio violador do Direito, ou seja 
aquele mesmo que arremeteu contra tais garantias, o poder de eficazmente fraudar, com o aval do ordenamento jurídico, a proteção que derivava do sobredito ordenamento, ter-se-á proclamado com isto a inanidade de tal proteção, a imoralidade como regra de conduta do Poder Público, a astúcia cavilosa como padrão do Direito e a vileza perante a Sociedade como princípio ético do Estado.

Cumpre não esquecer que as Constituições, que o próprio Estado de Direito, se constituem em um projeto de contenção do exercício do poder, em prol das liberdades e garantias do cidadão. É, pois, cabal contra-senso interpretar problemas jurídicos surdidos na intimidade deste entorno dando-lhes solução que avalize conceitos inversos aos que inspiram o Estado de Direito e a segurança que veio prover.

23. É induvidoso que Emendas Constitucionais, editadas nos limites que lhes são cabíveis, aportam modificações ao quadro constitucional anterior. E óbvio, de conseguinte, que servirão, dali por diante como bom fundamento de validade para as normas produzidas em sua consonância. Nada mais natural, então, que, por isto mesmo, sejam, em sucessão a ela, editadas leis conformes a estes novos termos, por muito gravosas que possam ser aos administrados, se comparadas com os termos dantes possíveis. Isto, todavia, não postula, nem lógica, nem jurídica, nem eticamente - e muito menos concorre para sustentação e prestígio do ordenamento - que deva recolher o que dantes era inconstitucional para abrigá-lo com um manto de resguardo, ainda que para infundir-lhe tal atributo tão-só para o futuro.

Propender para exegese deste feitio implicaria incorrer no contra-senso de reputar lógico que o ordenamento milite em desfavor da própria higidez e, demais disso, em considerar que o Direito prestigia ou é indiferente à fraude, à burla e não apenas a si próprio como aos integrantes da Sociedade. Não é de bom feitio hermenêutico enveredar por interpretações que sufraguem, em maior ou menor grau, a indulgência com elas, ou que lhes propicie a prática, o que, ocorrerá, entretanto, se a incursão em tais condutas for inconsequiente e se o beneficiário delas puder absorver os frutos de expedientes desta ordem.

24. O que se vem de anotar é sobreposse evidente nos casos em que a Emenda Constitucional é editada pouco depois da lei inconstitucional, evidenciando que busca remendar o vício que maculava dita lei.

Ressaltará, na hipótese, o objetivo de fraude, a conduta desleal, de má-fé, sendo certo, entretanto, que o primeiro obrigado a um comportamento liso, lhano, leal, é aquele que encarna a ordem jurídica, ou seja: o próprio Estado, tanto mais porque dispõe, em face da Sociedade, de todos os Poderes, com ressalva dos limites que a Constituição lhe impõe.

Já os mais vetustos textos de direito ressaltavam a exigência da honestidade como inerência do jurídico. Disse MODESTINO: "Semper in conjuntionis non solum quid liceat considerandum est sed et quid honestum sit", vale dizer: "Sempre nas vinculações, não só o que é lícito deve ser ponderado, senão também o que é honesto" 10 .

10 Cf. Rubens Limongi França, Brocardos Jurídicos, Ed. Rev. dos Tribunais, 1977, $3^{\text {a }}$ ed., pp. 89-90 e 134-135. 
Se fosse reconhecível ao Estado o direito de proceder de molde a absorver vantagens por meio de expedientes astuciosos por via dos quais frustrasse aos administrados colher os resultados da segurança que o próprio ordenamento thes propiciava, estar-se-ia não apenas deprimindo garantias constitucionais, mas também premiando a má-fé, o que seria inaceitável, maiormente perante a Constituição Brasileira que, expressamente, no art. 37, consagra o princípio da moralidade administrativa. o qual, "a fortiori", terá de vigorar perante o próprio Estado brasileiro no exercício de função ainda mais elevada, como o é a legislativa, maiormente a de Emendas Constitucionais.

25. Ora, o Direito abomina a má fé. Acresce que, mais que qualquer outro sujeito de direitos, está o Poder Público assujeitado ao princípio da boa fé, cuja importância apresenta, então, particular relevo na esfera das relações de direito público.

$O$ alumiado publicista espanhol, JESUS GONZALES PEREZ, em monografia preciosa sobre o princípio da boa fé em direito administrativo, tece ao respeito considerações que, por sua justeza, merecem transcrição literal:

"El de buena fe aparece como uno de los principios generales que sirvem de fundamento al Ordenamiento, informan la labor interpretativa y constituyen decisivo instrumento de integración" "I.

“... Como disse GUASP 'todos los campos del derecho estatal son clima propicio, como cualquier otro, al desarrollo de esta verdadera patologia de lo juridico $Y$ es más, ella se dá en el seno de los principales elementos que conjuga la relacion juridica estatal: la Autoridad y el súbdito'.

Porque, en efecto, la presencia de los valores de lealtad, honestidad y moralidad que su aplicación comporta es especialmente necesaria en el mundo de las relaciones de la Administración con los administrados" 12 .

Adverte que tal princípio:

"es exigible en los actos juridicos, en el ejercicio de los derechos y en el cumplimiento de las obligaciones". ${ }^{13}$

Note-se que sendo a boa fé um princípio geral de direito, a adoção de interpretações que o prestigiem, não significa uma liberalidade por parte do intérprete, seja ele juiz ou outro aplicador do Direito, mas representa atendimento obrigatório ao próprio sistema jurídico, pois como disse EDUARDO GARCIA DE ENTERRÍA, figura pinacular do direito público contemporâneo:

"Conviene recordar a este proposito que los principios generales del Derecho son una condensación de los grandes valores jurídicos materiales que constituyen el substractum del Ordenamiento y de la experiência reiterada de la vida juridica. No consisten, pues, en una abstracta e indeterminada invocación de la justicia o de la consciencia moral o de la discreción del juez, sino, más bien, en la expresión de

11 El Principio General de la Buena Fe en el Derecho Administrativo, Madrid, 1983, p.15.

12 Op cit., p. 31.

13 Op. cit.. p. 31. 
una justicia material especificada técnicamente en función de los problemas jurídicos concretos 'y objetivada en la lógica misma de las instituciones "."14 (grifos nossos).

26. Assim, na conformidade das considerações feitas, não há senão concluir que, dentre as alternativas exegéticas em tese suscitáveis perante o tema de leis originariamente desconformes com a Constituição, mas comportadas por Emenda Constitucional superveniente, a única merecedora de endosso é a que apresentamos como a quarta delas, ou seja: aquela segundo a qual a sobrevinda de Emenda não constitucionaliza a norma inicialmente inválida. Dessarte. seus efeitos poderão ser impugnados e desaplicada tal regra. Para que venham a irromper validamente no universo jurídico efeitos correspondentes aos supostos na lei originariamente inválida será necessário que, após a Emenda, seja editada nova lei, se o legislador entender de fazê-lo e de atribuir-lhe teor igual, pois, só então, será compatível com o enquadramento constitucional vigente.

Tal conclusão, ainda que, " argumentandum tantum", não fosse induvidosamente a solução adequada para a generalidade das hipóteses - como entendemos que é - sê-lo-ia ao menos, perante Emendas Constitucionais produzidas logo em seguida a lei inconstitucional. Deveras, se acolhida "constitucionalização" em tais condições, a exegese que a acolhesse estaria a prestar-se para acobertar propósito fraudulento, imoral. em descompasso com o art. 37 da Constituição e com princípios gerais de Direito.

27. Em síntese conclusiva, pois. não há senão dizer que Emenda Constitucional - diferentemente de uma nova Constituição — não é ruptura com o ordenamento jurídico anterior, mas, pelo contrário, funda-se nele, nele se integra e representa sua continuidade, donde seria inadmissível entender que tem o efeito de "constitucionalizar". ainda que daí para o futuro. leis originariamente inconstitucionais. Deveras, tal intelecção. propiciaria fraude ao próprio ordenamento. pois ensejaria e confortaria sua burla, efetuável mediante produção de leis inconstitucionais em antecipação a Emendas futuras ou, dito pelo inverso, ensejaria o bloqueio do reconhecimento de inconstitucionalidades, graças ao expediente de produzir emenda sucessiva. Inclinar-se por exegese conducente a tais resultados implicaria abraçar o contra-senso de reputar lógico que o ordenamento milite em seu próprio desfavor, isto é. o de que previamente assume que, se for burlado, tal burla será aprovada, validada e confortada por seu aval protetor. Nisto estaria, então, implicado que o Direito prestigia ou é indiferente à fraude, à burla, não apenas a si próprio como aos membros da Sociedade, inobstante o Estado de Direito seja concebido como instrumento de proteção aos cidadãos contra o exercício desatado do Poder. Dessarte, ficaria afiançada a inanidade de tal proteção.

Logo, não é de admitir que Emenda Constitucional superveniente a lei inconstitucional, mas com ela compativel, receba validação dali para o futuro. Antes, ter-se-á de entender que se o legislador desejar produzir nova lei e com o mesmo teor, que o faça, então, editando-a novamente, já agora — e só agora — dentro de

14 Curso de Derecho Administrativo, obra conjunta com Tomás Ramón Fernández, vol. 1. p. 400, Ed. Civitas, Madrid, 1981, reimpressāo da $3^{2} \mathrm{ed}$. 
possibilidades efetivamente comportadas pelo sistema normativo. Tal solução, única tolerável, é, quando menos, irretorquível nos casos em que a Emenda sucede a breve prazo a lei inconstitucional, patenteando o intuito de coonestar-lhe o vício. Em situações desta compostura, admitir a validação sucessiva da lei seria, em guisa de interpretar, promover consagração da imoralidade como regra de conduta do Poder Público, a astúcia cavilosa como padrão do Direito e a vileza perante a Sociedade como princípio ético do Estado. Nisto haveria ofensa frontal não apenas ao princípio da moralidade administrativa. previsto no art. 37 da Constituição (e maiormente vigorante para o Poder Público quando exerça a altaneira função de elaborar Emendas Constitucionais), mas também ao princípio geral de direito que reclama obediência aos cânones da lealdade e da boa fé e proscreve a má fé como pauta de conduta. 